University of Nebraska - Lincoln

DigitalCommons@University of Nebraska - Lincoln

$12-2005$

\title{
Assessment of ecological risks in weed biocontrol: Input from retrospective ecological analyses
}

Svata M. Louda

University of Nebraska - Lincoln, slouda1@unl.edu

Tatyana A. Rand

University of Göttingen, tatyana.rand@ars.usda.gov

F. Leland Russell

Wichita State University, leland.russell@wichita.edu

Amy E. Arnett

Unity College

Follow this and additional works at: https://digitalcommons.unl.edu/bioscifacpub

Part of the Life Sciences Commons

Louda, Svata M.; Rand, Tatyana A.; Russell, F. Leland; and Arnett, Amy E., "Assessment of ecological risks in weed biocontrol: Input from retrospective ecological analyses" (2005). Faculty Publications in the Biological Sciences. 86.

https://digitalcommons.unl.edu/bioscifacpub/86

This Article is brought to you for free and open access by the Papers in the Biological Sciences at DigitalCommons@University of Nebraska - Lincoln. It has been accepted for inclusion in Faculty Publications in the Biological Sciences by an authorized administrator of DigitalCommons@University of Nebraska - Lincoln. 
Published in Biological Control 35:3 (December 2005), pp. 253-264; special issue on “Science and Decision Making in Biological Control of Weeds: Benefits and Risks of Biological Control"; doi: 10.1016/j.biocontrol.2005.07.022 Copyright (C) 2005, published by Elsevier Inc. Used by permission. http://www.elsevier.com/locate/ybcon

Submitted July 16, 2004; accepted July 25, 2005; published online October 7, 2005.

\title{
Assessment of ecological risks in weed biocontrol: Input from retrospective ecological analyses
}

\author{
Svata M. Louda, ${ }^{1}$ Tatyana A. Rand, ${ }^{2}$ F. Leland Russell, ${ }^{3}$ and Amy E. Arnett ${ }^{4}$ \\ ${ }^{1}$ School of Biological Sciences, University of Nebraska-Lincoln, Lincoln, NE 68588-0118, USA \\ ${ }^{2}$ Department of Agroecology, University of Göttingen, Waldweg 26, D-37073 Göttingen, Germany \\ ${ }^{3}$ Biology Department, Wichita State University, Wichita, KS 67260, USA \\ ${ }^{4}$ Department of Environmental Programs, Unity College, Unity, ME 04988, USA \\ Corresponding author - S. M. Louda, fax 402 472-2083, email slouda@unl.edu
}

\begin{abstract}
Prediction of the outcomes of natural enemy introductions remains the most fundamental challenge in biological control. Quantitative retrospective analyses of ongoing biocontrol projects provide a systematic strategy to evaluate and further develop ecological risk assessment. In this review, we highlight a crucial assumption underlying a continued reliance on the host specificity paradigm as a quantitative prediction of ecological risk, summarize the status of our retrospective analyses of nontarget effects of two weevils used against exotic thistles in North America, and discuss our prospective assessment of risk to a federally listed, threatened species (Cirsium pitcheri) based on those studies. Our analyses quantify the fact that host range and preference from host specificity tests are not sufficient to predict ecological impact if the introduced natural enemy is not strictly monophagous. The implicit assumption when such use is made of the host specificity data in risk assessment is that population impacts are proportional to relative preference and performance, the key components of host specificity. However, in concert with shifting awareness in the field, our studies demonstrate that the environment influences and can alter host use and population growth, leading to higher than expected direct impacts on the less preferred native host species at several spatial scales. Further, we have found that straightforward, easily anticipated indirect effects, on intraguild foragers as well as on the less preferred native host plant species, can be both widespread and significant. We conclude that intensive retrospective ecological studies provide some guidance for the quantitative prospective studies needed to assess candidate biological control agent dynamics and impacts and, so, contribute to improved rigor in the evaluation of total ecological risk to native species.
\end{abstract}

Keywords: biocontrol costs, ecological risk assessment, Larinus planus, nontarget effects, Rhinocyllus conicus, landscape effects, local effects, spillover, weed control

\section{Introduction}

The challenge of biological control is to find natural enemies that will be effective in limiting the density of the pest species in its new environment, and do so without initiating ecological ripple effects with long-term consequences for the recipient community (Howarth, 1983, Louda et al., 2003a, 2003b; Simberloff and Stiling, 1996). However, prediction of the outcome and interactions of introduced natural enemies in new environments remains difficult (Louda et al., 2003a; McEvoy and Coombs, 2000). Quantitative retrospective ecological analyses of ongoing projects provide a systematic method to evaluate and to improve our predictive ability (see, e.g., Follett and Duan, 2000; Wajnberg et al., 2001). Such studies allow quantification of both direct and indirect effects associated with insects used for biocontrol following their host specificity testing and introduction. Furthermore, retrospective analyses provide an efficient way to validate emerging ideas for improved risk assessment, including consideration of relevant ecological 
parameters (e.g., van Lenteren et al., 2003) and to further develop prospective tests for future introductions of biological control agents. The latter use is demonstrated, for example, in our analysis of the ecological risk posed by Rhinocyllus conicus Frölich (Coleoptera: Curculionidae) to the federally listed rare North American Pitcher's thistle, Cirsium pitcheri (Torr. ex Eaton) Torr. \& A. Gray, prior to dispersal of $R$. conicus into this rare thistle's habitat (Louda et al., 2005).

We have three aims in this paper. First, we define the components of ecological risk and examine a critical assumption implicit in the predominant reliance on host specificity testing as a quantitative estimate of ecological risk in biocontrol. Second, we summarize the current status of our retrospective studies of the ecological interactions and nontarget impacts of two Eurasian weevils (R. conicus, Larinus planus (Fabricius)) used against exotic thistles in North America. Using these retrospective studies of unexpected or unexpectedly intense nontarget ecological effects, we review the application of the retrospective analyses in our prospective study and we discuss the implications of such analyses for future assessments of ecological risk to native plants and their interdependent, interacting species.

\subsection{Ecological risk}

The quantification of ecological risk has at least two dimensions. These include the: (1) determination of the likelihood or probability of any nontarget ecological interactions and (2) assessment of the magnitude of likely ecological impacts for the potential interactions uncovered. The former requires determination of the likely host range of the proposed agent. The latter requires quantification of the parameters mediating interaction intensities in the new environment. Thus, key parameters of overall ecological risk in such assessments include: (1) physiological host range, (2) ecological host range, (3) agent population growth and impact, and (4) effects in likely indirect interactions.

How, and to what extent, are these key parameters of ecological risk currently evaluated? Physiological host range, the list of host species that can be used as hosts, is generally measured by host specificity. Host specificity is defined as relative preference in feeding and oviposition among host species and relative suitability of those species for insect development (McEvoy, 1996; Schaffner, 2001; Zwölfer and Harris, 1971). Such tests are typically conducted under controlled conditions in laboratories or, less often and less extensively, in field cages. The tests are usually supplemented with field observations on host use in the native range. Physiological host range is currently the focus of most biocontrol risk assessments, and it is standard protocol in weed biological control projects (Louda et al., 2003b; McEvoy, 1996; Pemberton, 2000; Schaffner, 2001).

Ecological host range is a prediction of host use under the range of physical and biotic conditions in the new environment. Ecological host range should quantify the range and relative magnitude of host species use in the context of the full suite of physical conditions and ecological interactions that occur in the field. Currently, while recognized as important, quantification of ecological host range (if done) is usually based on extrapolation from observed field occurrences and the list of hosts within the home range (e.g., Balciunas et al., 1994; Blossey et al., 1994; Hajek et al., 1996; Pike et al., 1999), rather than on quantitative estimation of the magnitude and impact of alternative host species use in the new environment.

Population growth potential of the agent and likely impact on both targeted primary host species and nontargeted secondary host species are now acknowledged as important aspects of a prospective biocontrol agent evaluation (e.g., van Lenteren et al., 2003; USDA APHIS PPQ, 2001); yet, few prerelease studies have actually quantified these ecological traits for prospective biocontrol agents prior to release into new environments (Simberloff and Stiling, 1996). Evaluation of population growth potential and likely impacts in new environments requires investigation and understanding of the factors influencing population dynamics, growth, spread, and direct impact on host species at various resource levels and with varied resource mixes (Arnett and Louda, 2002; Byers, 2000; Byers and Noonburg, 2003; Denno and Peterson, 1996).

Finally, likelihood and potential magnitude of indirect ecological effects require study of the main interacting and dependent species within the likely recipient communities, and within the habitat range of the insect natural enemy in the new environment (e.g., Louda et al., 2003a; Pearson et al., 2000). Such analyses are not yet a standard part of biological control risk assessment prior to agent introduction or distribution. However, we have found that population-level responses in the new environment and their interactions with other species are not always accurately predicted by the relative preference and performance data taken for individual insects under laboratory, garden test conditions or native range patterns of use (Gassmann and Louda, 2001; Louda, 2000; Louda et al., 1997, 1998, 2003a, 2003b).

\subsection{Host range as an estimator of ecological risk}

Host specificity tests are designed to identify the host range of the insect (or the pathogen) natural enemy. These tests aim to determine acceptance and then relative rank or preference among the accepted species as well as relative suitability for insect or pathogen development (McEvoy, 1996; Schaffner, 2001). In contemporary studies, native relatives of the targeted species are usually included in the test list (Schaffner, 2001). In weed biological control testing in North America, host specificity has been quite successful in defining host range and the list of plant species likely to be observed as hosts in the field (Pemberton, 2000); and, its use in insect biological control projects now is advocated as well (Louda et al., 2003b; Pike et al., 1999).

However, since most insect species are not strictly monophagous (Brues, 1946; Essig, 1958; Singer and Lee, 2000), the host range of even the more specific insects considered 
for biocontrol introductions often includes some native species. These are accepted, though usually to a lesser extent, in the host specificity tests. For example, in pre-release testing Hylobius transversovitatus Goeze, the root-boring weevil recently released against purple loosestrife (Lythrum salicaria L), also fed and showed larval development on two native plant species, winged lythrum (L. alatum Pursh.) and swamp lythrum (Decodon verticillatus L.) (Blossey et al., 1994). Such "secondary" host species, based on preference and relative performance, are usually relatives of the targeted, presumably preferred exotic host plant (Louda et al., 2003b; Pemberton, 2000), and this was the case for L. alatum and D. verticillatus (Blossey et al., 1994). When feeding or oviposition on alternate or secondary hosts is lower than on the targeted host in tests, the inference has been made that impact in the new environment also will be low (e.g., Blossey et al., 1994; McClay, 1990; Olckers et al., 2002; Zwölfer and Harris, 1984). However, extrapolation of preference and performance of individuals, from laboratory data or field distributions in the indigenous environment, to predictions of ecological risk from population growth and use in the new environment field requires the assumption that population dynamics will scale with individual preference and relative performance. The implicit assumption is that population growth and impact on host species in the field are likely to be inversely proportional to their rank in a host specificity hierarchy. An alternative hypothesis, suggested by our data from retrospective studies, is that ecological factors can significantly alter population growth, host choice and use and, so, the agent's impact among acceptable host species from that expected based on the host specificity tests.

\subsection{Host specificity and nontarget population impacts}

Is the impact on nontarget species in the field inversely proportional to host specificity ranking? While knowledge of host range and specificity is clearly a crucial component of ecological risk assessment (Pemberton, 2000), several recent studies including our own on both $R$. conicus and $L$. planus impacts on native thistles demonstrate that the magnitude of the ecological risk to less preferred native species cannot always be predicted from host specificity or field distributions in the home range (Arnett and Louda, 2002, Louda, 1998, 2000; Louda and Arnett, 2000; Louda and O'Brien, 2002; Rand and Louda, 2004, 2005; Rand et al., 2004; Russell and Louda, 2004), nor can it predict indirect community effects (Pearson et al., 2000).

As an example, consider the impacts of the flower-head weevil, R. conicus on Platte thistle (Cirsium canescens Nutt.). This weevil was introduced into North America in 1968 as a biological control agent against the Eurasian Carduus spp. thistles, especially musk thistle (Carduus nutans L. complex) (reviewed by Gassmann and Louda [2001] and Zwölfer and Harris [1984]). The results of host-specificity tests conducted before introduction showed the weevil had: (1) a strong preference for Carduus spp. over most Cirsium spp., (2) faster development to larger adult size on Carduus spp. compared to Cirsium spp. evaluated under test conditions, and (3) relative restricted host range within each of the regions in which it was found in Europe (Gassmann and Louda, 2001; Zwölfer and Harris, 1984).

Although the laboratory tests showed some acceptance of Cirsium spp., including the one native North American species evaluated, both the host specificity tests and the field data prior to release, plus the observation that North American native species typically had lower population densities than did the targeted Carduus spp., led to the inference that $R$. conicus use of native Cirsium spp. would not be significant quantitatively; so, the magnitude of impact, if any, was expected to be small (Zwölfer and Harris, 1984). However, after R. conicus invaded our long-term study sites in midgrass Sand Hills prairie in 1993, seed production by both Platte thistle and wavyleaf thistle decreased significantly (Louda, 2000), and the numbers of Platte thistle plants in long-term demography plots has subsequently declined significantly (Figure 1A) as the numbers of R. conicus increased (Figure 1B), consistent with model predictions
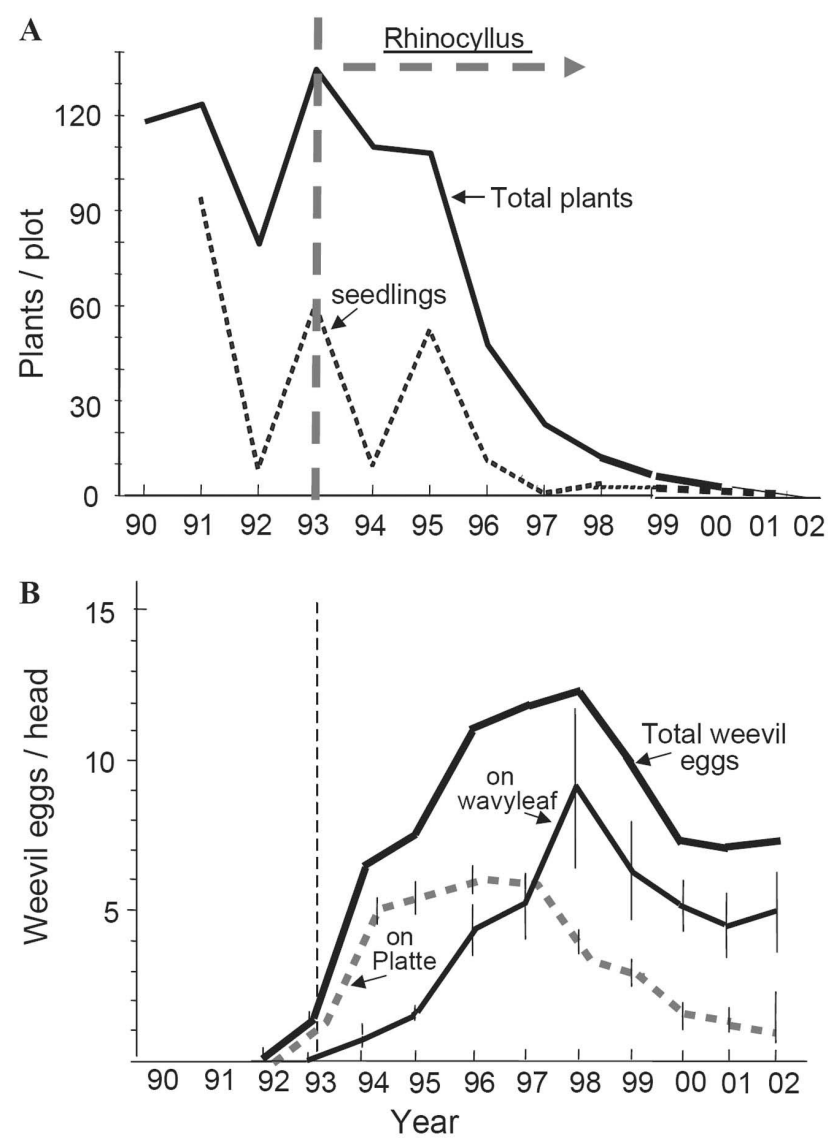

Figure 1. (A) Example of the change in number of Platte thistle (C. canescens) in demography plots initiated in 1990 at Arapaho Prairie TNC Preserve in the southwestern Sand Hills, Nebraska, showing seed limitation of recruitment and declining plant numbers after the invasion of the study site by R. conicus (adapted from Louda and Arnett, 2000, and unpublished data). (B) The numbers of $R$. conicus egg cases observed on flower heads of Platte thistle and wavyleaf thistle (C. undulatum) plants sampled destructively outside the demography plots each year: $N \geq 20$ C. canescens, $\geq 12$ C. undulatum per year (adapted from Louda, 2000 and S. M. Louda and colleagues, unpublished data). 
of R. conicus' demographic impact (Rose et al., 2005). Weevil impact on the native Platte thistle in a new habitat without its targeted Eurasian thistle occurred despite the continued strong preference of naturalized weevils for musk thistle (C. nutans) over Platte thistle (C. canescens) (Figures 2A and B).

Why did the information from host specificity testing and host range in the indigenous region fall short on predicting the magnitude of the nontarget impact of $R$. conicus on seed production, recruitment, and density of Platte thistle, a less preferred host plant? We have collected extensive observational and experimental data to examine this question retrospectively. These studies have highlighted two critically important factors of ecological host range and environmental conditions that influenced insect impact on this secondary native host plant species. First, the preferred host species musk thistle, C. nutans, does not occur at our sand prairie sites (Keeler et al., 1980; Lamp, 1980). Thus, preference and relative performance criteria were irrelevant to host selection, use, and impact on the less preferred native species in the Sand Hills prairie habitat into which the weevil dispersed. Second, phenological synchrony and the total resource pool available in the environment are needed in order to explain the level of use of a co-occurring native thistle species within this habitat.

The two native species of thistles that occur most commonly in the Sand Hills region are Platte thistle (C. canescens) and wavyleaf thistle (Cirsium undulatum (Nutt.) Spreng.). The factors determining the level of $R$. conicus use of the two native species differ. Weevil egg load on wavyleaf thistle initially has been lower than egg load on
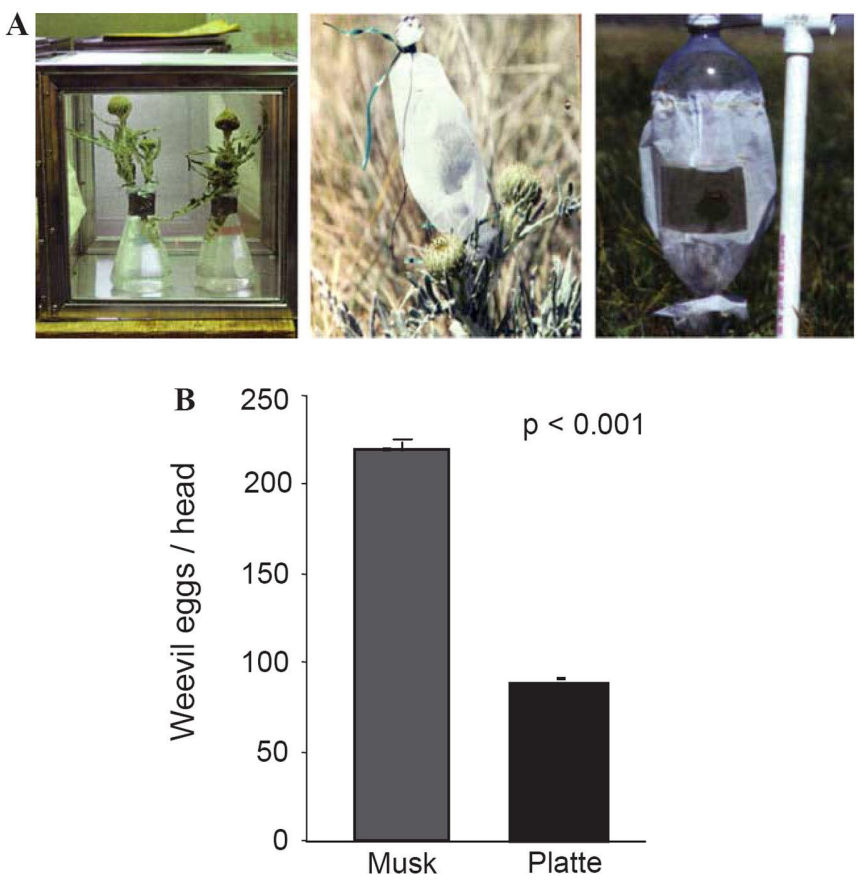

Figure 2. (A) Laboratory and field cages used to evaluate host specificity of $R$. conicus. (B) Evidence of continued strong preference of $R$. conicus for musk thistle (C. nutans spp. leiophyllus), when it is available under laboratory conditions (adapted from Arnett and Louda, 2002).
Platte thistle (Louda, 1998, 2000). We found much lower phenological overlap between the $R$. conicus oviposition period and flowering by wavyleaf thistle than flowering by Platte thistle (Figure 3A; Russell and Louda, 2004, in press). In fact, the most significant factor in explaining quantitative variation in $R$. conicus egg load on Platte thistle is the degree of synchrony between Platte thistle flowering and $R$. conicus adult activity among sites and among years (Figure $3 \mathrm{~B}$ ), instead of other physical or biological factors that were expected to be important (Russell and Louda, 2004).

For the later-flowering wavyleaf thistle, however, R. conicus egg load was best explained not by direct factors but rather by the availability of Platte thistle flower heads. Using previously published methods in a parallel study (Russell and Louda, 2004), we found that $R$. conicus egg load on wavyleaf thistle increased as the availability of Platte thistle flower heads decreased, both among sites and among years (Russell and Louda, in press). Thus, the impact of R. conicus on wavyleaf thistle cannot be predicted without knowledge
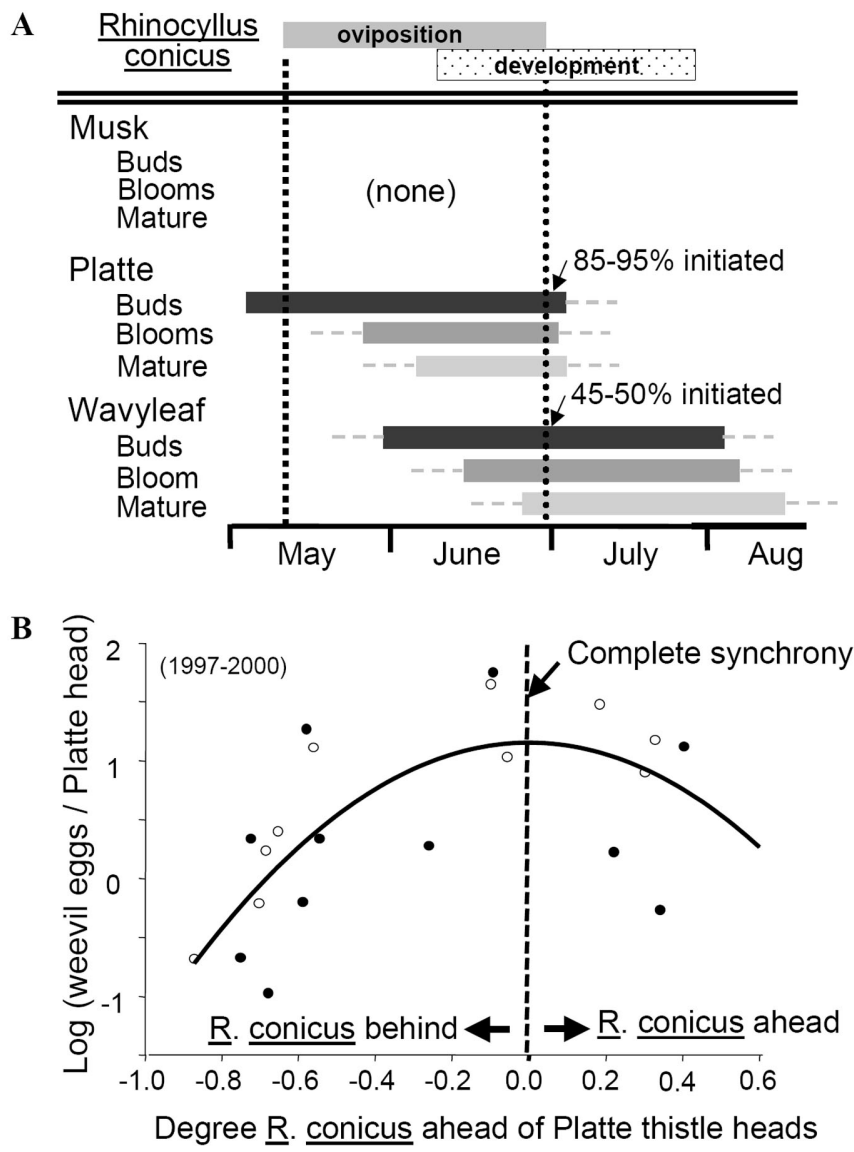

Figure 3. (A) Phenological availability of flower head resources for $R$. conicus in the Sand Hills prairie study site, by potential host species, showing almost complete overlap between $R$. conicus and the native Platte thistle (C. canescens) and significant overlap as well with wavyleaf thistle (C. undulatum), both in the absence of any of the preferred host plant, C. nutans. (B) Evidence that the magnitude of the effect on Platte thistle is mediated by the degree of synchrony between adult $R$. conicus and flowering phenology of Platte thistle, showing that the more closely the two are synchronized, the greater the $R$. conicus egg load on Platte thistle (adapted from Russell and Louda [2004] and unpublished data). 
of the availability of Platte thistle flower head resources. There is an indirect interaction between the two native plant species in the new environment that determines the level of infestation on the second species to flower in the new environment. Overall, it is clear that ecological factors of the new environment, and not relative preference, relative performance or relative choice among host species in the indigenous environment, determine the levels of nontarget impacts by $R$. conicus on native thistles that are secondary host species in the plains of North America.

\subsection{Host specificity and unexpectedly large nontarget ef-} fects of L. planus

The $R$. conicus case represents one of the most intensive quantitative retrospective analyses of nontarget effects by an insect used for biological control of weeds to date (reviewed by Gassmann and Louda, 2001; Louda et al., 2003a). Although the case is not unique (see Follett and Duan, 2000; Howarth, 1991; Simberloff and Stiling, 1996; Stiling, 2004; Wajnberg et al., 2001), it has been challenged as unusual (Boldt, 1997). Since few ecological studies have been done in biological control programs, other cases in which native species are acceptable secondary hosts for introduced biological control agents need more intensive ecological analyses to address this issue (see, e.g., Diehl and McEvoy, 1990).

We recently discovered, for example, unexpectedly large nontarget effects for another Eurasian weevil (L. planus) that is currently being distributed in North America against Canada thistle, Cirsium arvense (L.) Scop. (Louda and O'Brien, 2002). Although L. planus is considered an accidental introduction (White, 1972), it was evaluated early on in Europe (Zwölfer, 1964; Zwölfer et al., 1971) and again more recently in Canada prior to redistribution there (McClay, 1990). Both sets of studies suggested that use of native North American species by L. planus could occur. However, the higher preference and performance of L. planus on the exotic coevolved, targeted plant $(C$. arvense) in the host specificity tests were interpreted, as usual, as evidence that no major impact on the native species was likely (McClay, 1990).

Unfortunately, the inference was wrong. L. planus now is significantly reducing seed production by Tracy's thistle, C. undulatum (Nutt.) Spreng. var. tracyi (Rydb.) Welsh, a sparse native species in western Colorado and eastern Utah (Louda and O'Brien, 2002), more than that of co-occurring plants of its targeted weed, C. arvense. Furthermore, L. planus is reported to have colonized multiple native thistle species in the western USA (G. Dodge et al., University of Maryland, College Park, Maryland, unpublished data; E. Coombs, Oregon Department of Agriculture, Portland, Oregon, personal communication 2004). In 1999, while looking for R. conicus, we found L. planus feeding in flower heads of Tracy's thistle near a 1992-1993 biocontrol release site. In the sample of flower heads collected, $74 \%$ had evidence of L. planus, and these heads produced only 1.1 vi- able seeds on average, compared to 45.9 in heads without this weevil (Louda and O'Brien, 2002). In 2000, we found that L. planus feeding persisted on Tracy's thistle at several sites, and weevil feeding reduced its seed production significantly (Figure 4).

Furthermore, the impact on Tracy's thistle was greater than its effect on Canada thistle (Louda and O'Brien, 2002). For example, less than $1 \%$ of the Canada thistle flower heads sampled had evidence of feeding by L. planus, likely due to the later flowering of Canada thistle in the study region (Louda and O'Brien, 2002). Yet, such evidence of $L$. planus feeding occurred on $80 \%$ of the Tracy's thistle plants and in $76 \%$ of all the main heads on those plants. Tracy's thistle flower heads with $L$. planus averaged 1.4 viable seeds, compared with 44.5 in uninfested heads. Feeding by L. planus decreased the average number of viable seeds produced per Tracy's thistle plant by over $51 \%$.

Thus, host specificity tests accurately defined the physiological host range, but not the ecological host range and level of nontarget impacts observed in the field. Environmental conditions again influenced the magnitude of the nontarget impacts observed and altered the relative levels of use of target and nontarget host species in the field from that expected based on the feeding tests and field observations prior to 1990. This case reinforces the conclusion that more effective a priori quantification of the potential numerical effects of a candidate biological control agent on nontargeted secondary host species, under realistic simulations of likely field conditions in the new environment prior to release or distribution of biocontrol agents, is needed to accurately evaluate the magnitude of ecological risk posed.

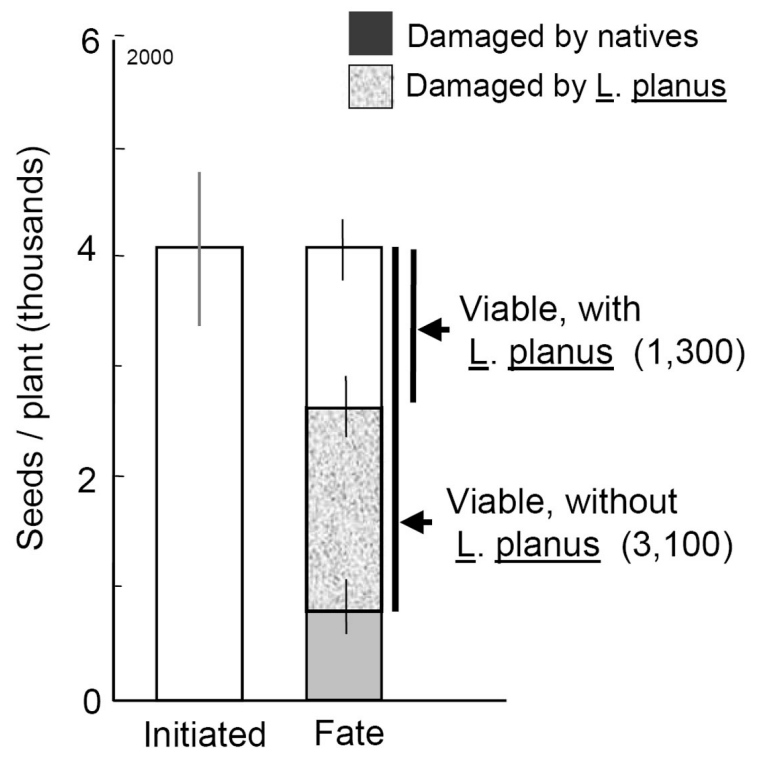

Figure 4. The fate of florets and potential seeds initiated by the sparse Tracy's thistle, C. undulatum var. tracyi, native to the Gunnison Basin, Colorado, showing that viable seed production of this sparse thistle is severely reduced by L. planus, an adventitious weevil from the northeast released in the Gunnison Basin against its coevolved Eurasian host plant Canada thistle, C. arvense, which is not being impacted by the weevil in this region (adapted from Louda and O'Brien, 2002). 
1.5. Factors affecting variation in the magnitude of use and potential impact?

To evaluate ecological factors influencing the magnitude of impact by $R$. conicus on seed production and performance of native thistle host species, we quantified variation in egg load on Platte thistle (C. canescens) and on wavyleaf thistle (C. undulatum) in prairies occurring on both sand and loam soils of the state across three spatial scales - biogeographic, landscape, and local. We used these data to evaluate one of the current hypotheses for the magnitude of nontarget effects in the new associations: that nontarget effects generally represent localized and temporary "spillover" from the buildup of a biocontrol agent's population on the targeted host plant species. Some previous empirical work supports this "spillover hypothesis," with evidence of nontarget feeding on native species in the proximity of the preferred targeted weed by high density populations of a biocontrol agent (Blossey et al., 2001). For Platte thistle, the hypothesis suggests that $R$. conicus attack and impacts should be locally restricted, and correlated with proximity to concentrations of the targeted weed species with high populations of the weevil. Recent theoretical studies have suggested that such "spillover" effects also could be important at larger spatial scales (Holt and Hochberg, 2001).
To examine this hypothesis, we quantified $R$. conicus use of Platte thistle (C. canescens) across the $54,000 \mathrm{~km}^{2}$ Sand Hills prairie region of Nebraska (1996-1998), the center of its distribution and abundance and a region in which the targeted weed is generally uncommon (Great Plains Flora Association, 1986, 1997). Flower heads were collected at 101 sites $>20 \mathrm{~km}$ apart across the Sand Hills region in 1996, 1997, and 1998; these samples were dissected and numbers of $R$. conicus, $R$. conicus egg cases, and other insects recorded (Rand and Louda, 2005). We found that $R$. conicus attacked Platte thistle throughout its entire range (Figure 5A). Thus, contrary to expectation based on the spillover hypothesis, population build-up was not restricted to plants in close proximity to the targeted weed, but occurred on individuals of this secondary, less preferred nontarget host species (Arnett and Louda, 2002) across its habitat range even in the absence of its targeted host species. Furthermore, $R$. conicus abundances on and damage to Platte thistle were highest in all three years in the central part of the Sand Hills (Figure 5B), furthest away from the eastern and southcentral midgrass loam soils areas with large musk thistle population (Rand and Louda, 2005). This study provides strong evidence against the hypothesis that nontarget effects can be explained as a temporary, local scale spillover effect in this system. Ecological conditions
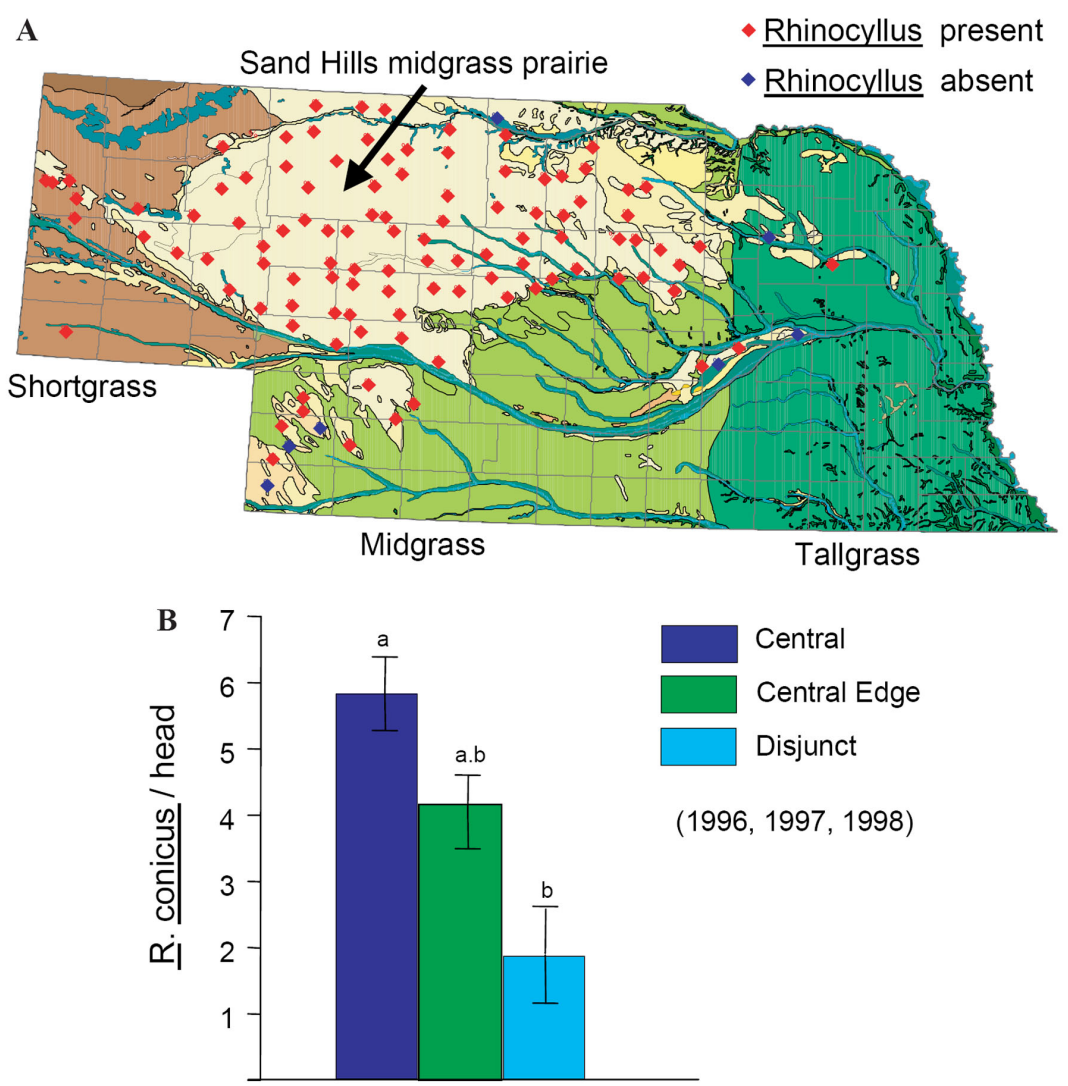

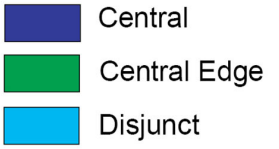

$(1996,1997,1998)$

Figure 5. (A) The distribution of R. conicus on Platte thistle (C. canescens) across the sand prairie (Sand Hills and disjunct sand outcrops) in Nebraska, showing the weevil has spread across the entire distribution of the native plant in the upper central Great Plains. (B) The number of $R$. conicus developing on average per Platte thistle flower head by region within the plant's distribution in Nebraska, showing unexpectedly that the numbers of $R$. conicus are highest in the center of the plant's distribution and farthest from the midgrass and tallgrass prairie habitats in which the targeted musk thistle is most common (Adapted from Rand and Louda, 2005). 
are affecting the amount of use of this native secondary host, independent of the preference, relative performance, and natural history of the weevil in its home range.

To analyze the potential contribution of various factors to the pattern of interaction on the biogeographic scale, we used structural equation modeling, a path analysis method that uses maximum likelihood estimation techniques to estimate path coefficients (Johnson et al., 1991). We found that environmental context was important in prediction of insect impact on the nontarget host (Figure 6). The number of $R$. conicus on Platte thistle was best predicted by two significant direct effects, geographic location within the Sand Hills (Figure 5B) and water-holding capacity in the root zone, and one weak indirect effect, the effect of growing degree-days and plant size (height) on the number of Platte thistle flower heads per plant (Figure 6). Variation in temperature and precipitation across the region did not contribute significantly to the pattern of $R$. conicus on Platte thistle (Figure 6; Rand and Louda, 2005). Thus, the retrospective analysis of nontarget interactions of $R$. conicus with C. canescens on the larger biogeographic scale strongly suggests the importance of resource availability and the physical location within the habitat in explaining the level of use and impact on this secondary nontarget host plant species under field conditions in the new environment.

For wavyleaf thistle (C. undulatum), a widespread species that occurs more commonly in midgrass prairie on better loam soils along with musk thistle, we also asked whether population buildup of $R$. conicus on the invasive exotic musk thistle influenced the magnitude of attack on co-occurring plants of this native thistles. Again, the hypothesis was that

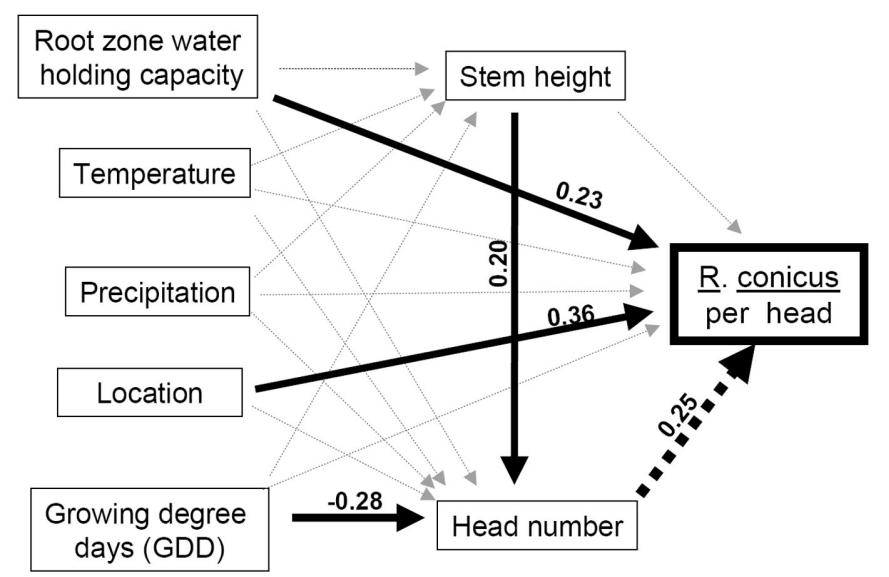

Figure 6. Path analytical assessment of the relative strengths of likely factors in the determination of $R$. conicus numbers on Platte thistle (C. canescens) throughout the sand prairie in Nebraska, showing that among the factors examined, $R$. conicus numbers correlated significantly and directly with location (see Figure 5B) and root zone water holding capacity. In addition, $R$. conicus numbers were influenced indirectly by a weak, but significant interaction of growing degree days and stem height effects affecting number of flower heads available to the weevil (Adapted from Rand and Louda, 2005). spillover from population build-up on musk thistle would explain the use of wavyleaf thistle by $R$. conicus. At the local scale, we quantified weevil egg densities on the native C. undulatum growing at different distances $(0-100 \mathrm{~m})$ from patches of the exotic thistle. We found that egg densities on the native thistle declined significantly with distance: within, vs. $30-50 \mathrm{~m}$, vs. $80-100 \mathrm{~m}$ from a musk thistle patch (Figure 7; Rand et al., 2004). High egg loads on wavyleaf thistle in the vicinity of the targeted host are consistent with a strong local spillover effect; this finding also suggests that ecological context (proximity to the targeted host) affects the level of nontarget impacts on this secondary species.

At a larger scale, we measured $R$. conicus egg densities on C. undulatum within grassland landscapes $(2.4 \times 2.4$ $\mathrm{km}$ ) with varying levels of infestation (densities) of the invasive musk thistle (2001-2002). We quantified a pattern of $R$. conicus use of wavyleaf thistle (C. undulatum) in relation to the occurrence of the invasive musk thistle $(C$. nutans) that is consistent with the "spillover" hypothesis (Rand and Louda, 2004), similar to that observed at the local scale (Rand et al., 2004). Egg densities of R. conicus on wavyleaf thistle increased significantly as invasive thistle densities increased (Figure 8), measured at both the local site and landscape scales in midgrass prairie on good loam soils (Rand and Louda, 2004). Since R. conicus feeding can substantially reduce seed production of wavyleaf thistle (Louda, 2000), we conclude that unsuppressed populations of the exotic musk thistle continue to have a significant negative indirect effect on this native North American thistle when it co-occurs with the targeted exotic thistle, both at the local site scale and at the landscape scale.

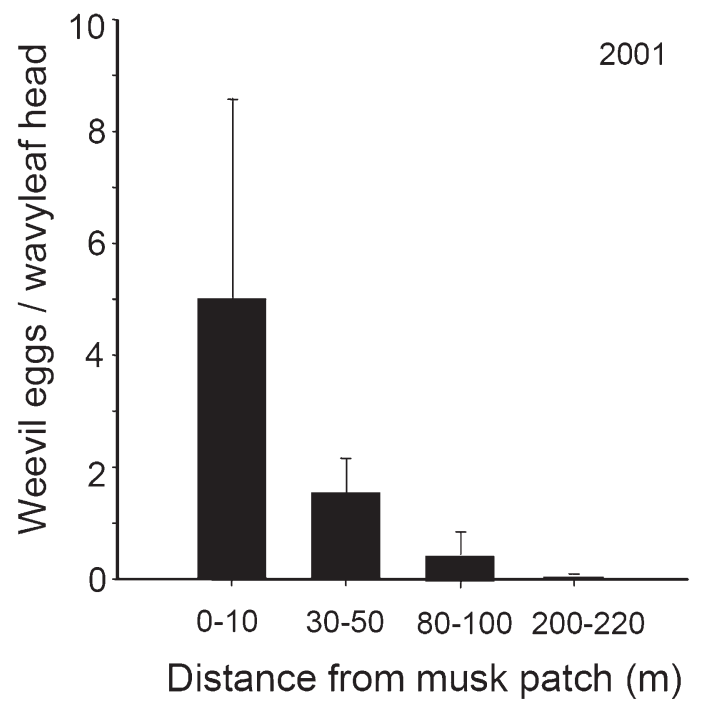

Figure 7. Local-scale relationship between numbers of $R$. conicus egg cases oviposited onto flower heads of the native wavyleaf thistle $(C$. undulatum) for plants that occur in midgrass prairie, the habitat with the targeted musk thistle, with distance from the nearest musk thistle patch, showing the significant "spillover" of R. conicus onto the secondary native host species occurs even in the vicinity, or with availability of, the preferred host plant (adapted from Rand et al., 2004; F. L. Russell et al., unpublished data). 

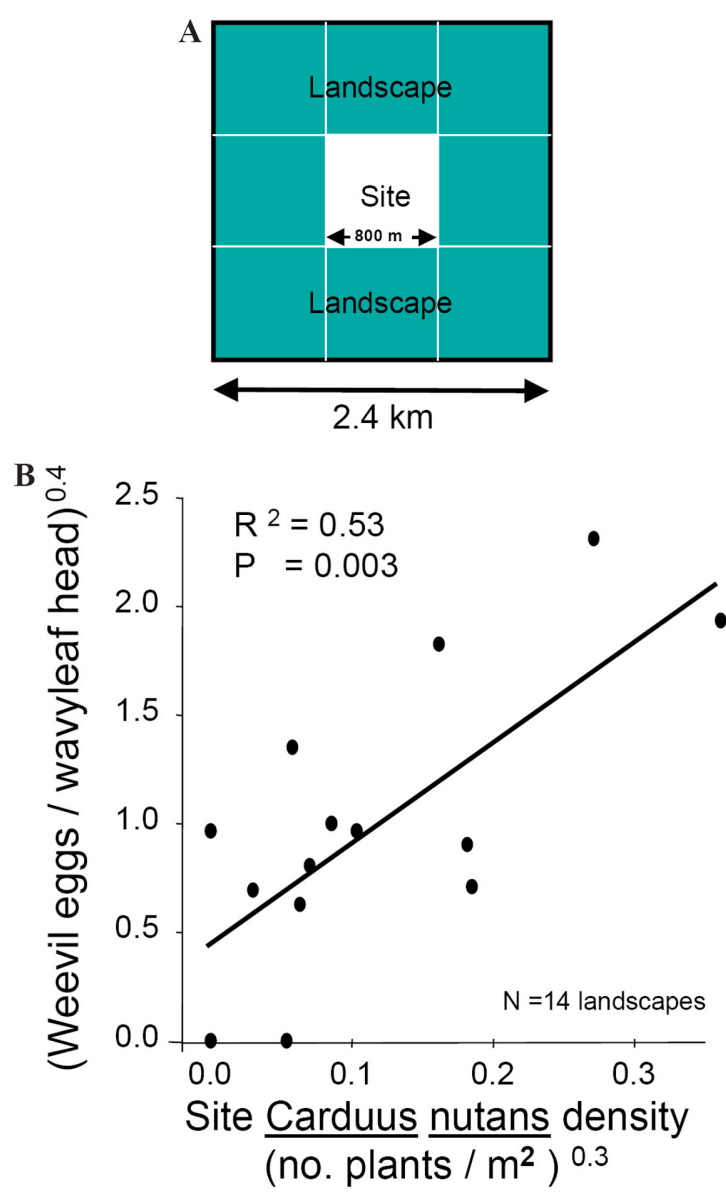

Figure 8. Landscape-scale relationship between numbers of $R$. conicus egg cases oviposited onto flower heads of the native wavyleaf thistle (C. undulatum) for plants that occur in midgrass prairie, in relation to landscape density of the preferred host plant, musk thistle (C. nutans), showing that significant "spillover" of $R$. conicus onto the secondary native host species also occurs at this larger scale when the unsuppressed exotic targeted weed provides a resource for the population build-up of the shared herbivore natural enemy (adapted from Rand and Louda, 2004).

The results of these local and landscape scale analyses of $R$. conicus use of the native wavyleaf thistle in midgrass prairies on loamy soils, where the targeted musk thistle often co-occurs, provide strong empirical evidence that nontarget impacts on a native, less preferred host plant species can actually be augmented by the release and build-up of a marginally effective biocontrol agent, one that allows the persistence of large stands of the targeted exotic plant. These findings are the first to substantiate theoretical predictions of this type of indirect interaction between plants mediated by a biological control agent (Holt and Hochberg, 2001). The interaction is a form of "apparent competition," an indirect negative interaction between two plant species that is mediated by a shared insect herbivore, the biocontrol weevil $R$. conicus in this case. Further, it is clear that ecological context again had a significant influence and that it altered the level of risk observed to populations of a native plant that is only a "secondary" host for the biological control insect based on host specificity criteria.
1.6. Intraguild indirect interactions with native floral herbivores

Finally, one intriguing but not well explored set of nontarget interactions with the introduction of a new species into a community involves the potential niche overlap of the introduced herbivore with the native insect herbivores dependent upon the native secondary host plants. The potential for both direct and indirect negative effects exists. Our retrospective studies suggest that these potential interactions can and should be assessed in risk assessments prior to the introduction of the new biological control agent. Quantification of interactions both in the home range and in the new environment, as well as laboratory and field cage experiments in both retrospective and prospective studies, can be used to ask: which herbivore species are present on the potentially acceptable nontarget native host plants? How and when do they or will they interact with each other and potentially with the proposed biological control agent? And how might key interactions be modified and populations affected by the addition of a potential competitor for the targeted resources of the agent's guild and interacting guilds mediated by the host plant?

In the case of $R$. conicus on Platte thistle, we have studied the interactions and effects of $R$. conicus on a native picture-winged fly, Paracantha culta (Diptera: Tephritidae), a characteristic thistle specialist (Lamp, 1980; Lamp and McCarty, 1982a, 1982b). The success of this native fly is relatively easy to document since it pupates within the flower heads and leaves the pupal case behind as evidence of successful development. This fly uses small to medium-sized thistle flower heads, both very early (first generation) and later (second generation) in the growing season (Lamp, 1980; Lamp and McCarty, 1982a, 1982b). In the Sand Hills prairies, where we have quantified thistle flowering since 1990 (Louda, 2000), P. culta is dependent upon Platte thistle, especially in the early season when it is the only thistle observed initiating flowering early enough to be a host for the first generation (S. M. Louda, unpublished data).

In our experiments, the number of $P$. culta flies developing successfully decreased as the number of R. conicus developing increased (Figure 9). The mechanisms implicated in our experiments include: (1) alteration of oviposition behavior by the fly in the presence of evidence of $R$. conicus (Louda and Arnett, 2000), (2) preemptive exploitation in the smaller flower heads, i.e., whoever got there first precluded development by the other species; as well as (3) resource competition in larger flower heads, i.e., fewer and/or smaller individuals developed when the other species was present (S. M. Louda and colleagues, unpublished data). The net effect of these interactions has been an inverse relationship between numbers of $R$. conicus and $P$. culta among heads, sites, and years, suggesting strong direct and indirect intraguild interactions on the secondary host species. 


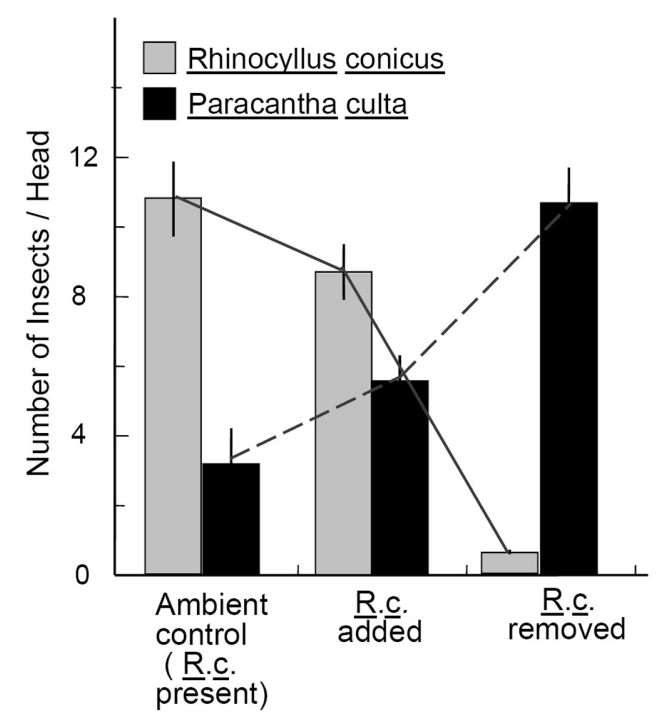

Figure 9. The number of the native tephritid fly, P. culta, developing successfully in an experimental manipulation of presence/absence of $R$. conicus, including the ambient control with $R$. conicus present, showing that addition of $R$. conicus even at less than ambient densities reduces successful development of $P$. culta whereas removal of $R$. conicus egg cases significantly increases the number of $P$. culta that develop in the field experiments (Louda and Arnett, 2002; S. M. Louda et al., unpublished manuscript).

In summary, retrospective studies of these interactions provide an abundance of evidence that environmental influences affect the outcome of various interactions that occur after release in a new region. Further, these effects are not well predicted by a continuing reliance on the typical protocols for risk assessment in weed biological control, specifically reliance on host specificity tests and native range host use that determine host range without specific measurement of factors influencing the magnitude of use of alternative host plant species, including the potential secondary hosts.

\subsection{Application: prospective analysis of risk for a listed rare thistle}

One immediate application of the results from this series of retrospective analyses of the factors and processes leading to significant nontarget effects of $R$. conicus was a prospective analysis of the ecological risk posed by $R$. conicus to a rare federally listed North American thistle, C. pitcheri Torrey \& Gray (Louda et al., 2005). This thistle, which is listed as threatened in the US (US Fish and Wildlife Service, 2002) and endangered in Canada (Environment Canada, 2004), occurs in the intermittent dune ecosystem along the shores of the Great Lakes of North America. Pitcher's thistle is currently protected in several National Lakeshore Parks (US Fish and Wildlife Service, 2002).

When we discovered the magnitude of the impact of $R$. conicus on Platte thistle (C. canescens), Pitcher's thistle's closest relative, we speculated that $R$. conicus also represented a threat to this rare species even though it is not yet present in this thistle's protected habitat (Louda et al., 1997). This inference was challenged, based on a lack of data (Boldt, 1997). To evaluate the risk quantitatively, we combined host specificity tests and garden rearing data with the evaluation of ecological field data on relative phenology, suggested as important by the retrospective studies summarized above, to prospectively evaluate the likelihood and magnitude of the potential interaction of $R$. conicus with C. pitcheri (Louda et al., 2005). While phenology is recognized as important in insect-plant interactions (e.g., Russell and Louda, 2004; Tikkanen and Julkunen-Tiitto, 2003), we found no prior studies that quantified the degree of likely phenological synchrony between a biocontrol agent and a potential secondary host plant species prior to contact.

Using both no-choice and choice laboratory-feeding and oviposition tests, we found that the rare Pitcher's thistle is well within the physiological host range of $R$. conicus. In fact, it is highly acceptable to $R$. conicus for adult feeding and oviposition and for larval development. In our tests, we found no strong preference for the coevolved musk thistle (Figure 10A), and equal or greater acceptance of Pitcher's thistle as Platte thistle (Louda et al., 2005), the closely related species that we know is being impacted by $R$. conicus (Louda, 2000; Louda and Arnett, 2000). In addition, the spontaneous colonization of potted C. pitcheri plants by $R$. conicus in a research garden in Alberta, Canada, demonstrated the weevil's natural ability to find and utilize the rare native thistle species; we found that larval development from egg to adult was highly successful on this rare species (Louda et al., 2005).

Furthermore, phenological data on plant flowering at 4 and 5 sites, respectively, within each of two National Lakeshore Parks (Sleeping Bear Dunes National Lakeshore, Empire, MI and Indiana Dunes National Lakeshore, Porter, IN) over three years (1993-1995) were compared to information on the weevil activity period both north and south of the distributional range of Pitcher's thistle. We found that the likely overlap varied from $80 \%$ to $99 \%$ of the total number of the flower heads per plant in the northern and southern parks, respectively (Louda et al., 2005). An example of the analysis (Figure 10B) illustrates the high overlap of plant flowering phenology with the likely activity period of the weevil in the habitat at four sites within Indiana Dunes National Lakeshore, using conservative estimates of the weevil's timing and activity (Louda et al., 2005).

In addition, a simple population projection matrix model, based on three years of demographic data at two sites, suggests that inclusion of $R$. conicus into the floral guild of Pitcher's thistle will lead to a decrease in $\lambda$, the annual rate of population growth, from a nearly stable level $(\lambda=0.990)$ by either $12 \%(\lambda=0.869)$ or $15 \%(\lambda=0.840)$ per year, depending upon the specific assumptions used (see Louda et al., 2005). The cumulative consequence of such decreases in $\lambda$ can be seen by examining the change in the time required to halve the population $\left(t_{0.5}\right)$. Under current conditions without $R$. conicus $(\lambda=0.990)$, the time to halve the population $\left(t_{0.5}\right)$ is $66.9 \mathrm{yr}$. However, with $R$. conicus 


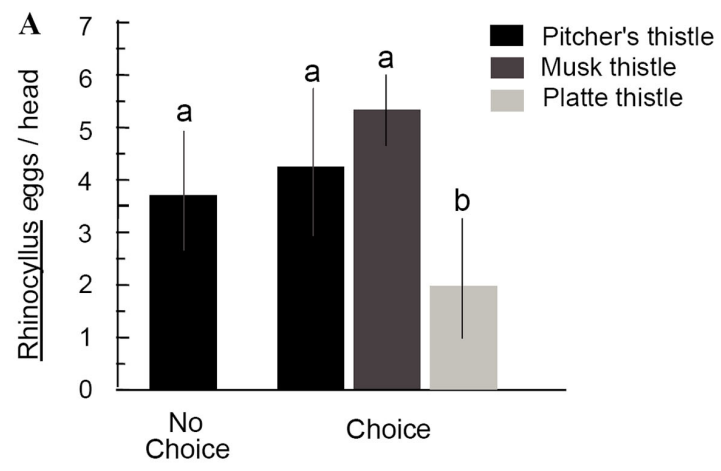

B Indiana Dunes National Lakeshore

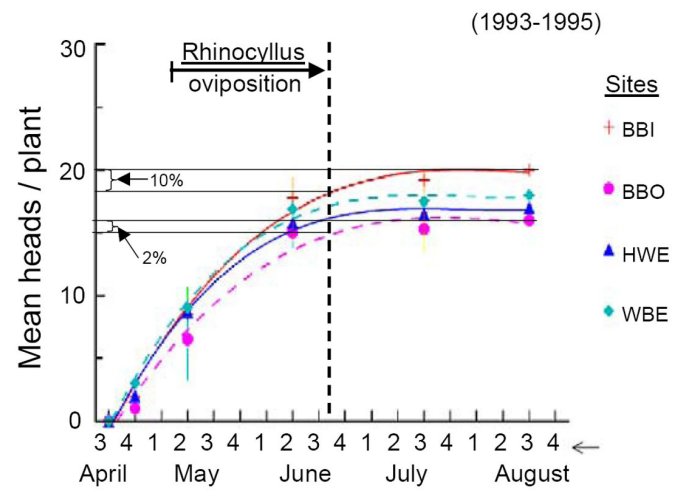

Figure 10. Prospective analysis of the acceptability, preference, suitability and phenological availability to $R$. conicus of the threatened Pitcher's thistle in the dunes along the Great Lakes of North America, protected habitat which has not yet been invaded by R. conicus. (A) Choice and no choice laboratory oviposition tests, supplemented with data on development (Louda et al., 2005) show that Pitcher's thistle is within the physiological host range of $R$. conicus; (B) field evidence of phenological overlap between the likely oviposition period of $R$. conicus and the flowering phenology of Pitcher's thistle, showing that $90-98 \%$ of the flower heads will be vulnerable to oviposition by R. conicus (adapted from Louda et al., 2005).

added to the floral insect herbivore guild, the estimated time to halve the population $\left(t_{0.5}\right)$ drops to between 4.0 and 4.9 yr $(\lambda=0.869-0.840)$.

Clearly, the prospective analysis of the potential effects of $R$. conicus on Pitcher's thistle, based upon retrospective studies combining laboratory and garden tests elsewhere with quantitative field data on parameters hypothesized to be important, suggests that the weevil has the potential of imposing a significant negative effect on the populations of an already threatened native plant. The case also illustrates the way in which quantitative or experimentally derived ecological data can be added to the host specificity data to improve the estimation of ecological risk in biocontrol.

\section{Summary and conclusion}

Host specificity tests are the best tool presently available to determine likely host range. Thus, the probability of feeding, oviposition, and development on a set of non- target native species, at least under test conditions, can and should be estimated. However, the other major component of ecological risk, the magnitude of direct population effects on nontarget native species and the likely indirect ecological effects associated with use of the secondary native host species, cannot be evaluated directly from host specificity. The little recognized, implicit assumption, when physiological host range information is extrapolated as an estimate of ecological host range, is that population impact will be proportional to relative preference and performance and, so, relatively independent of environment and ecological context. Our retrospective studies, reviewed above, do not support this fundamental assumption underlying the use of host specificity as a measure to total ecological risk. Likely interaction strengths are required, as well as host range.

Better ways to evaluate the second component of ecological risk, the magnitude of likely interaction strengths, are needed if any native species are accepted even marginally as secondary hosts in the host specificity tests. We conclude that our intensive retrospective ecological studies of $R$. conicus on native thistles reinforce the suggestions that the magnitude component of risk, and the role of ecological factors in it, now need more careful quantification to produce accurate assessments of total ecological risk to native species. Influential factors of ecological range in our studies included: phenology and phenological synchrony, population growth and density in response to environmental variation, population growth at various resource levels and mixes, as well as population dispersal (rates, success, limits), and the direct and indirect effects of physical factors and biotic interactions on plant and insect performances, and modification of interactions across multiple spatial scales of the interactions.

Determinants of the level of resource use, and its consequences for alternative host plant populations, that are required to estimate demographic consequences of consumption, are not yet routinely quantified. For example, if dispersal potential is quantified, then it is usually done after the fact once release has been made (e.g., Center et al., 1997). Yet, many or most of the factors above could be evaluated quantitatively a priori, using clever experiments and modeling. One example of the value and application of retrospective analyses is use of the inferences in prospective analyses, such as our analysis of the threat posed by $R$. conicus to the very rare Pitcher's thistle should it disperse or be distributed into this rare plant's protected habitat around the Great Lakes of North America.

Our studies document the occurrence of direct effects on native host species in the same guild as the targeted species, as well as indirect effects within that guild that were mediated by their shared natural enemy - the biocontrol agent. Furthermore, we have found evidence of added direct and indirect effects on a native herbivore species dependent upon the nontarget secondary host plant. Clearly, these studies suggest that both the direct and indirect effects of the proposed biocontrol agents on accepted second- 
ary host species, and their dependent species, need to be considered and evaluated quantitatively if the objective is to quantify total ecological risk associated with biocontrol technology. Our studies suggest some ways to evaluate important dimensions of the potential interactions that could be done stepwise before introduction. Once these risks are quantified, comparable data can be required for alternative management options.

In summary, the conclusion that host specificity estimates ecological risk, which rests on an often unrecognized assumption that population dynamics are proportional to relative preference and performance, needs explicit recognition and direct evaluation. Our results clearly challenge this assumption, and the evidence now argues strongly that environmental context, dispersal dynamics, and the spatial scale of the interactions of introduced insects with native secondary host plant species influence the second important component of ecological risk, the likely magnitude of nontarget impacts on secondary host species and their associates. Thus, the effect of environment context and varying scale on likely interaction outcomes needs to be quantified prior to introduction in order to realistically predict the overall environmental costs to be weighed against the proposed environmental benefits of a deliberate introduction of a new exotic species in an effort to manage invasive exotic weed.

\section{Acknowledgments}

We thank the many conscientious and cheerful research students, critical colleagues, interested friends, and supportive family members that contributed to the projects summarized. We also are grateful to the numerous Nebraskans who generously granted us permission to work on their private property. Funding for the work was provided by The National Science Foundation (DEB 9221065, DEB9616210), the Katherine Ordway and Rodney Johnson Stewardship Funds of The Nature Conservancy, D. H. Smith Conservation Research Fellowship from The Nature Conservancy (T.A.R.), USDA-NRI grant 2001-35320-09882, and the University of Nebraska Research Council.

\section{References}

Arnett and Louda, 2002 A. E. Arnett and S. M. Louda, Re-test of Rhinocyllus conicus host specificity, and the prediction of ecological risk in biological control, Biol. Conserv. 106 (2002), pp. 251-257.

Balciunas et al., 1994 J. K. Balciunas, D. W. Burrows, and M. F. Purcell, Field and laboratory host ranges of the Australian weevil, Oxyops vitiosa (Coleoptera: Curculionidae), a potential biological control agent for the paperbark tree, Melaleuca quinquenervia, Biol. Control 4 (1994), pp. 351-360.

Blossey et al., $1994 \longrightarrow$ B. Blossey, D. Schroeder, S. D. Hight, and R. A. Malecki, Host specificity and environmental impact of the weevil Hylobius transversovittatus, a biological control agent of purple loosestrife (Lythrum salicaria), Weed Sci. 42 (1994), pp. 128-133.

Blossey et al., 2001 B. Blossey, R. Casagrande, L. Tewksbury, D. A. Landis, R. N. Wiedenmann, and D. R. Ellis, Nontarget feeding of leaf-beetles introduced to control purple loosestrife (Lythrum salicaria L. ), Nat. Areas J. 21 (2001), pp. 368-377.
Boldt, 1997 Boldt, P. E., 1997. Response of a Rhinocyllus researcher. Biocontrol News Inf. $18,100 \mathrm{~N}$.

Brues, $1946 \longrightarrow$ C. T. Brues, Insect Dietary, Harvard University Press, Cambridge, MA (1946).

Byers, $2000 \longrightarrow$ J. E. Byers, Competition between two estuarine snails: Implications for invasions of exotic species, Ecology 81 (2000), pp. $1225-1239$.

Byers and Noonburg, 2003 J. E. Byers and E. G. Noonburg, Scale dependent effects of biotic resistance to biological invasion, Ecology 84 (2003), pp. 1428-1433.

Center et al., 1997 T. D. Center, J. H. Frank and F. A. Dray, Biological control. In: D. Simberloff, D. C. Schmitz, and T. C. Brown, eds., Strangers in Paradise: Impact and Management of Nonindigenous Species in Florida, Island Press, Washington, DC (1997), pp. 245-264.

Denno and Peterson, 1996 R. F. Denno and M. A. Peterson, Density-dependent dispersal and its consequences for population dynamics. In: N. Cappuccino and P. W. Price, eds., Population Dynamics: New Approaches and Synthesis, Academic Press, San Diego, CA (1996), pp. 113-130.

Diehl and McEvoy, 1990 J. W. Diehl and P. B. McEvoy, Impact of the cinnabar moth (Tyria jacobaeae) on Senecio triangularis, a non-target native plant in Oregon. In: E. S. Delfosse, ed., Proceedings of the VII International Symposium on the Biological Control of Weeds, Instituto Sperimentale per la Patologia Vegetale Ministero dell'Agricoltura e delle Foreste, Rome, Italy (1990), pp. 119-126.

Environment Canada, 2004 Environment Canada, 2004. Species at Risk Act Public Registry. Schedule 1: List of Species at Risk; accessed March 15, 2004, at http://www.sararegistry. gc.ca/species/schedules_e.cfm?idD1

Essig, 1958 E. O. Essig, Insects and Mites of Western North America (Revised ed. ), Macmillan Company, New York (1958).

Follett and Duan, $2000 \longrightarrow$ P. Follett and J. Duan, Nontarget Effects of Biological Control, Kluwer Academic Publishers, Dortrecht/Boston/London (2000).

Gassmann and Louda, 2001 A. Gassmann and S. M. Louda, Rhinocyllus conicus: Initial evaluation and subsequent ecological impacts in North America. In: E. Wajnberg, J. K. Scott and P. C. Quimby, eds., Evaluating Indirect Ecological Effects of Biological Control, CABI Publishing, CABI International, Wallingford, Oxon, UK (2001), pp. 147-183.

Great Plains Flora Association, 1997 Great Plains Flora Association, 1977. Atlas of the Flora of the Great Plains. Iowa State University Press, Ames, IA.

Great Plains Flora Association, 1986 Great Plains Flora Association, 1986. Flora of the Great Plains. University Press of Kansas, Lawrence, KS.

Hajek et al., 1996 A. E. Hajek, L. Butler, S. R. A. Walsh, J. C. Silver, F. P. Hain, F. L. Hastings, T. M. Odell, and D. R. Smitley, Host range of the gypsy moth (Lepidoptera: Lymantriidae) pathogen Entomophaga maimaiga (Zygomycetes: Entomophthorales) in the field versus the laboratory, Env. Entomol. 25 (1996), pp. 709-721.

Holt and Hochberg, $2001>$ R. D. Holt and M. E. Hochberg, Indirect interactions, community modules and biological control: A theoretical perspective. In: E. Wajnberg, J. K. Scott and P. C. Quimby, eds., Evaluating Indirect Ecological Effects of Biological Control, CABI Publishing, Wallingford, Oxon, UK (2001), pp. 13-37.

Howarth, 1983 F. G. Howarth, Classical biocontrol: Panacea or Pandora's box?, Proc. Hawaiian Entomol. Soc. 24 (1983), pp. 239-244.

Howarth, 1991 - F. G. Howarth, Environmental impacts of classical biological control, Annu. Rev. Entomol. 36 (1991), pp. 485-509.

Johnson et al., 1991 M. L. Johnson, D. G. Huggins, and J. DeNoyelles, Ecosystem modeling with LISREL: A new approach for measuring direct and indirect effects, Ecol. Appl. 1 (1991), pp. 383-398.

Keeler et al., $1980 \triangleright$ K. H. Keeler, A. T. Harrison, and L. Vescio, The flora and Sand Hills prairie communities of Arapaho Prairie, Arthur County, Nebraska, Prairie Naturalist 12 (1980), pp. 65-78.

Lamp, $1980 \backslash$ W. O. Lamp, Predispersal seed predation of the Platte thistle and its effect on seed production. Ph. D. Thesis, University of Nebraska, Lincoln, 1980.

Lamp and McCarty, 1982a W. O. Lamp and M. K. McCarty, Biology of predispersal seed predators of the Platte thistle Cirsium canescens, J. Kansas Entomol. Soc. 55 (1982), pp. 305-316. 
Lamp and McCarty, 1982b W. O. Lamp and M. K. McCarty, Predispersal seed predation of a native thistle, Cirsium canescens, Environ. Entomol. 11 (1982), pp. 847-851.

van Lenteren et al., $2003 \rightarrow$ J. C. van Lenteren, D. Babendreier, F. Bigler, B. G. Burgio, H. M. T. Hokkanen, S. M, Kuske, A. J. Loomans, I. Menzler-Hokkanen, P. C. J. Van Rijn, M. B. Thomas, M. G. Tommasini, and Q. Q. Zeng, Environmental risk assessment of exotic natural enemies used in inundative biological control, BioControl 48 (2003), pp. 3-38.

Louda, 1998 S. M. Louda, Population growth of Rhinocyllus conicus (Coleoptera: Curculionidae) on two species of native thistles in prairie, Env. Entomol. 27 (1998), pp. 834-841.

Louda, 2000 S. M. Louda, Negative ecological effects of the musk thistle biocontrol agent, Rhinocyllus conicus Fröl. In: P. A. Follet and J. J. Duan, eds., Nontarget Effects of Biological Control, Kluwer Academic Publishers, Boston, MA (2000), pp. 215-243.

Louda and Arnett, 2000 S. M. Louda and A. E. Arnett, Predicting non-target ecological effects of biological control agents: Evidence from Rhinocyllus conicus. In: N. R. Spencer, ed., Proceedings of the 10th International Symposium on the Biological Control of Weeds, Montana State University, Bozeman, MT (2000), pp. 551-567.

Louda and O'Brien, 2002 S. M. Louda and C. W. O'Brien, Unexpected ecological effects of distributing the exotic weevil, Larinus planus (F. ), for the biological control of Canada thistle, Conserv. Biol. 16 (2002), pp. 717-727.

Louda et al., $1997 \longrightarrow$ S. M. Louda, D. Kendall, J. Connor, and D. Simberloff, Ecological effects of an insect introduced for the biological control of weeds, Science 277 (1997), pp. 1088-1090.

Louda et al., 1998 S. M. Louda, D. Simberloff, G. Boettner, J. Connor, D. Kendall, and A. E. Arnett, Insights from data on the nontarget effects of the flowerhead weevil, Biocontrol News Inf. 26 (1998), pp. $70 \mathrm{~N}-71 \mathrm{~N}$.

Louda et al., 2003a S. M. Louda, A. E. Arnett, T. A. Rand, and F. L. Russell, Invasiveness of some biological control insects challenges adequacy of ecological risk assessment and regulation, Conserv. Biol. 17 (2003), pp. 1-11.

Louda et al., 2003b $>$ S. M. Louda, R. W. Pemberton, M. T. Johnson, and P. A. Follett, Nontarget effects - The Achilles' heel of biological control? Retrospective analyses to reduce risk associated with biocontrol introductions, Annu. Rev. Entomol. 48 (2003), pp. 365-396.

Louda et al., 2005 S. M. Louda, T. A. Rand, A. E. Arnett, A. S. McClay, K. Shea, and A. K. McEachern, Evaluation of ecological risks to populations of a threatened plant from an invasive biocontrol insect, Ecol. Appl. 15 (2005), pp. 234-249.

McClay, $1990-$, A. S. McClay, The potential of Larinus planus (Coleoptera: Curculionidae), an accidentally-introduced insect in North America, for biological control of Cirsium arvense. In: E. S. Delfosse, ed., Proceedings of the 7th International Symposium on the Biological Control of Weeds, March 6-11, 1988. Instituto Sperimentale per la Patologia Vegetale Ministero dell'Agricoltura e delle Foreste, Rome, Italy (1990), pp. 173-179.

McEvoy, 1996 P. B. McEvoy, Host specificity and biological pest control, BioScience 46 (1996), pp. 401-405.

McEvoy and Coombs, 2000 P. B. McEvoy and E. M. Coombs, Why things bite back: Unintended consequences of biological control of weeds. In: P. A. Follett and J. J. Duan, eds., Nontarget Effects of Biological Control, Kluwer Academic Publishers, Boston, MA (2000), pp. 176-194.

Olckers et al., 2002 T. Olckers, J. C. Medal, and D. E. Gandolfo, Insect herbivores associated with species of Solanum (Solanaceae) in northeastern Argentina and southeastern Paraguay, with reference to biological control of weeds in South Africa and the United States of America, Florida Entomol. 85 (2002), pp. 254-260.

Pearson et al., 2000 D. E. Pearson, K. S. McKelvey, and L. F. Ruggiero, Non-target effects of an introduced biological control agent on deer mouse ecology, Oecologia 122 (2000), pp. 121-128.
Pemberton, $2000 \triangleright$ R. W. Pemberton, Predictable risk to native plants in weed biological control, Oecologia 125 (2000), pp. 489-494.

Pike et al., 1999 K. S. Pike, P. Stary, T. A. Miller, D. Allison, G. Graf, L. Boydston, R. E. Miller, and R. Gillespie, Host range and habitats of the aphid parasitoid Diaeetiella rapae (Hymenoptera: Aphidiidae) in Washington State, Env. Entomol. 28 (1999), pp. 61-71.

Rand and Louda, $2004 \longrightarrow$ T. A. Rand and S. M. Louda, Exotic weed invasion increases the susceptibility of native plants to attack by a biocontrol herbivore, Ecology 85 (2004), pp. 1548-1554.

Rand and Louda, 2005 T. A. Rand and S. M. Louda, Invasive insect abundance varies across the biogeographic distribution of a newly adopted host plant. Ecol. Appl., in press (2005).

Rand et al., 2004 T. A. Rand, F. L. Russell, and S. M. Louda, Local vs. landscape scale indirect effects of an invasive weed on native plants, Weed Technol. 18 (2004), pp. 1250-1254.

Rose et al., 2005 K. E. Rose, S. M. Louda, and M. Rees, Demographic and evolutionary impacts of native and invasive insect herbivores on Cirsium canescens, Ecology 86 (2005), pp. 453-465.

Russell and Louda, 2004 F. L. Russell and S. M. Louda, Phenological synchrony affects interaction strength of an exotic weevil with Platte thistle, a native host plant, Oecologia 139 (2004), pp. 525-534.

Russell and Louda, in press - F. L. Russell and S. M. Louda, Indirect interaction between two native thistles mediated by an invasive exotic floral herbivore. Oecologia, in press (2005).

Schaffner, 2001 U. Schaffner, Host range testing of insects for biological weed control: How can it be better interpreted?, BioScience 51 (2001), pp. 951-959.

Simberloff and Stiling, $1996>$ D. Simberloff and P. Stiling, How risky is biological control?, Ecology 77 (1996), pp. 1965-1974.

Singer and Lee, $2000 \triangleright$ M. C. Singer and J. R. Lee, Discrimination within and between host species by a butterfly: Implications for design of preference experiments, Ecol. Lett. 3 (2000), pp. 101-105.

Stiling, $2004-$ P. Stiling, Biological control not on target, Biol. Invasions 6 (2004), pp. 151-159.

Tikkanen and Julkunen-Tiitto, $2003 \rightarrow$ O. P. Tikkanen and R. Julkunen-Tiitto, Phenological variation as protection against defoliating insects: The case of Quercus robur and Operophtera brumata, Oecologia 136 (2003), pp. 244-251.

USDA APHIS PPQ, 2001 USDA, Animal and Plant Health Inspection Service, Plant Protection and Quarantine, 2001. Reviewer's Manual for the Technical Advisory Group for Biological Control Agents of Weeds: Guidelines for Evaluating the Safety of Candidate Biological Control Agents. First ed. Online at http://www.aphis.usda.gov/ $\mathrm{ppq} / \mathrm{ss} / \mathrm{tag} / \mathrm{tag} . \mathrm{html}$

US Fish and Wildlife Service, 2002 US Fish and Wildlife Service, 2002. Pitcher's Thistle (Cirsium pitcheri) Recovery Plan. Fish and Wildlife Reference Service, Bethesda, MD, Fort Snelling, MI.

Wajnberg et al., $2001 \longrightarrow$ E. Wajnberg, J. K. Scott, and P. C. Quimby, Evaluating Indirect Ecological Effects of Biological Control, CABI Publishing, CABI International, Wallingford, Oxon, UK (2001).

White, $1972 \longrightarrow$ J. C. White, A European weevil, Larinus carlinae Oliver, collected in Maryland, Coop. Economic Insect Rep. 22 (1972), p. 418.

Zwölfer, 1964 Zwölfer, H., 1964. Weed projects for Canada. Progress Report No. X: Larinus and Rhinocyllus. Commonwealth Institute of Biological Control, European Station, Delemont, Switzerland.

Zwölfer et al., 1971 H. Zwölfer, K. E. Frick, and L. A. Andres, Study of host plant relationships of European members of the genus Larinus (Col. : Curculioinidae), Tech. Bull. Commonw. Inst. Biol. Control 14 (1971), pp. 97-141.

Zwölfer and Harris, 1971 H. Zwölfer and P. Harris, Host specificity determination of insects for biological control of weeds, Annu. Rev. Entomol. 16 (1971), pp. 159-178.

Zwölfer and Harris, 1984 H. Zwölfer and P. Harris, Biology and host specificity of Rhinocyllus conicus (Froel. ) (Col., Curculionidae), a successful agent for biocontrol of the thistle, Carduus nutans L., Z. Angew. Entomol. 97 (1984), pp. 36-62. 